\title{
Scrotal Liposarcoma
}

National Cancer Institute

\section{Source}

National Cancer Institute. Scrotal Liposarcoma. NCI Thesaurus. Code C156282.

A liposarcoma involving the scrotum. 